\title{
Bone marrow cell therapy for heart disease: A few good men and women wanted
}

Shafie Fazel, MD, PhD

See related article on page 717 .
From the Division of Cardiac Surgery, Toronto General Hospital, University Health Network, University of Toronto, Toronto, Ontario, Canada.

Received for publication Oct 1, 2006; revisions received Oct 14, 2006; accepted for publication Oct 25, 2006.

Address for reprints: Shafie Fazel, MD, PhD, 4N-466, Toronto General Hospital, 200 Elizabeth Street, Toronto, Ontario, Canada M5G2C4 (E-mail: shafie.fazel@sympatico.ca).

J Thorac Cardiovasc Surg 2007;133:599-600 0022-5223/ $\$ 32.00$

Copyright $(9) 2007$ by The American Association for Thoracic Surgery

doi:10.1016/j.jtcvs.2006.10.029
$\mathrm{M}$ ore than a decade ago, the concept of cell replacement therapy to treat heart failure was born. ${ }^{1}$ The initial framework proposed that if congestive heart failure is caused by the loss of contractile units in the heart, then replacement of contractile units should reverse heart failure. Initially, fetal cardiomyocytes were used, but the implanted cells did not beat with the rest of the cardiomyocytes, and the cells remained functionally isolated. Other muscle cell types, including skeletal myoblasts and smooth muscle cells, also failed to adopt a contractile phenotype. The implantation of these noncontractile units, however, was shown to improve cardiac function. It was argued that the implantation of autologous contractile units would improve cardiac function above and beyond that accomplished with noncontractile cells, and the search began to shift from committed muscle cells to noncommitted stem cells that could potentially be induced to become cardiomyocyte like.

A flurry of activity ensued, and in the rush to discover this new landscape, one is left with the impression that a few tumbled. Although a handful of groups focused on the embryonic stem cells, the majority turned to an autologous source of stem cells to avoid the ethical quagmire that accompanies the use of embryonic stem cells for therapeutic purposes. Scientists knew the bone marrow stem cells well. Reports emerged that hematopoietic stem cells could transdifferentiate into cardiomyocytes. This was convenient because the bone marrow is easy to aspirate, and the stem cells are easy to purify with our currently available technology. On the basis of two reports in mice, ${ }^{2,3}$ clinical trials were organized and carried out with feverish activity across the globe. ${ }^{4}$ Various bone marrow cell preparations were infused or injected into the heart. Some observers might have been heard in the background whispering primum non nocere because the biology of bone marrow cell implantation into injured myocardium had not been rigorously examined.

Amid this surge of activity, three reports simultaneously emerged that demonstrated that hematopoietic stem cells do what hematopoietic stem cells are supposed to do and no more; even when injected into the heart they give rise to hematopoietic progeny and not to cardiomyocytes. ${ }^{5-7}$ Few implored the field to re-examine the rationale that guided the design of clinical trials of bone marrow cell therapy. ${ }^{8}$

In retrospect, there existed neither biological precedence nor teleological justification for expecting the hematopoietic stem cells to overachieve above and beyond their known biology and to transdifferentiate to cardiomyocytes. However, observers pointed out that even in the absence of any sort of transdifferentiation, infusion or implantation of the stem cells still appeared to improve cardiac function in the mouse model. ${ }^{5}$ Therefore the improvement in cardiac function must be independent of the transdifferentiation of the cells to cardiomyocytes; that is, the cells might have unforeseen beneficial effects that we clearly do not understand. If the cells do not transdifferentiate, they probably achieve their benefit through paracrine elaboration 
of factors, ${ }^{9}$ but this aspect of the biology of cell implantation is poorly understood. In other words, there is still no biological rationale for trials of bone marrow cell therapy for ischemic heart disease, at least as we stand today.

The present article is by one of the first groups of investigators that set out on the clinical path to evaluate the efficacy of cell transplantation into the ischemic cardiomyopathic heart at the time of coronary artery bypass grafting $(\mathrm{CABG}) .{ }^{10} \mathrm{I}$ congratulate them for having persevered with the current trial, which is a natural continuation of the previous one.

The authors chose AC133-expressing CD34 bright bone marrow endothelial progenitor cells, which is a relatively pure population. This subpopulation of cells, however, also includes the progenitor cells for granulocytes, macrophages, and possibly erythrocytes. ${ }^{11}$ Certainly basic science data convincingly suggest that this cell population could be quite beneficial in inducing angiogenesis in ischemic tissue. The wide range of cell doses $\left(1.2-80 \times 10^{6}\right.$ cells) that were implanted into the patients makes it difficult to interpret some of the safety and efficacy data. On the basis of the mouse data, in which approximately $1 \times 10^{5}$ cells were implanted, the weight-adjusted cell dose for human subjects should probably be closer to the higher cell dose that Stamm and colleagues ${ }^{10}$ used.

The authors included patients with a previous myocardial infarction. Initially, all patients had distinct areas of akinesis that corresponded to the region of infarction. It would have been valuable if the viability within these akinetic regions was also evaluated. A viable but akinetic segment is anticipated to resume function after adequate blood flow is restored with CABG. A nonviable and akinetic scar is unlikely to derive benefit from CABG alone. Also, the effect of the cells might be entirely different when transplanted in viable versus nonviable scars. In the former the cells might restore function by inducing angiogenesis. In the latter the effect of the cells on the matrix within the scar is likely to be far more important than the effect of the cells on angiogenesis. I would agree with the first inclusion criteria that excluded patients with global dysfunction. One of the other patient variables, which I recognize is difficult to control, is whether the diseased artery supplying the akinetic area is grafted. It appears as though the authors constructed a bypass in some cases in which it was feasible but not in others when the artery was not bypassable. Although this is a reflection of real life, it makes the interpretation of the efficacy data more difficult.

The authors began their trial with an appropriate 1:1 randomization protocol. I share the authors' frustration in having to give up the randomization scheme because of logistic issues. In addition, the issue of appropriate control subjects will continue to be a difficult one in this field because bone marrow aspiration in the CABG-only group is quite invasive, but if bone marrow aspiration is not done, it would unblind the patient and the caregiver to the treatment received. Perhaps the patients should undergo a sham bone marrow aspiration to minimize the placebo effect. Also, the CABG-only group should receive equivalent needle punctures into the akinetic segments to further limit variation between the groups.

As this study confirms, the cell injection appears to be safe. Concerns regarding induction of arrhythmias exist with cell therapy, and I think all patients should have appropriate monitoring, safety devices available, or both Implantation of an internal defibrillator would satisfy both criteria but is invasive. Short-term telemetry does not capture late arrhythmias, but induction of arrhythmia probably has a high early hazard ratio.

It is encouraging that the implantation of the cells improved the ejection fraction by $6.3 \%$, but interpretation of this datum should be made within the context of some of the above issues. I agree with the author's conclusion that larger randomized and controlled studies are clearly warranted. I think the future trials should include a homogenous group of patients with clear delineation of viable versus nonviable myocardium and use a narrow cell dose and, most importantly, should be performed in a blinded, randomized, and controlled setting. A few good men and women are wanted to perform such a study. Dr Christof Stamm and colleagues certainly appear to be in a unique position to continue to push to ripen this field.

\section{References}

1. Murry CE, Field LJ, Menasche P. Cell-based cardiac repair: reflections at the 10-year point. Circulation. 2005;112:3174-83.

2. Orlic D, Kajstura J, Chimenti S, Jakoniuk I, Anderson SM, Li B, et al Bone marrow cells regenerate infarcted myocardium. Nature. 2001; 410:701-5.

3. Orlic D, Kajstura J, Chimenti S, Limana F, Jakoniuk I, Quaini F, et al. Mobilized bone marrow cells repair the infarcted heart, improving function and survival. Proc Natl Acad Sci U S A. 2001;98:10344-9.

4. Fazel S, Tang GH, Angoulvant D, Cimini M, Weisel RD, Li RK, et al. Current status of cellular therapy for ischemic heart disease. Ann Thorac Surg. 2005;79(suppl):S2238-47.

5. Balsam LB, Wagers AJ, Christensen JL, Kofidis T, Weissman IL, Robbins RC. Haematopoietic stem cells adopt mature haematopoietic fates in ischaemic myocardium. Nature. 2004;428:668-73.

6. Murry CE, Soonpaa MH, Reinecke H, Nakajima H, Nakajima HO, Rubart M, et al. Haematopoietic stem cells do not transdifferentiate into cardiac myocytes in myocardial infarcts. Nature. 2004;428:664-8.

7. Nygren JM, Jovinge S, Breitbach M, Sawen P, Roll W, Hescheler J, et al. Bone marrow-derived hematopoietic cells generate cardiomyocytes at a low frequency through cell fusion, but not transdiffer entiation. Nat Med. 2004;10:494-501.

8. Chien KR. Stem cells: lost in translation. Nature. 2004;428:607-8.

9. Fazel S, Cimini M, Chen L, Li S, Angoulvant D, Fedak P, et al. Cardioprotective c-kit + cells are from the bone marrow and regulate the myocardial balance of angiogenic cytokines. J Clin Invest. 2006; 116:1865-77.

10. Stamm C, Westphal B, Kleine HD, Petzsch M, Kittner C, Klinge H, et al. Autologous bone-marrow stem-cell transplantation for myocardial regeneration. Lancet. 2003;361:45-6.

11. Yin AH, Miraglia S, Zanjani ED, Almeida-Porada G, Ogawa M, Leary AG, et al. AC133, a novel marker for human hematopoietic stem and progenitor cells. Blood. 1997;90:5002-12. 